\title{
Covid-19 Dan Perubahan Komunikasi Sosial
}

\author{
Jeratallah Aram Dani ${ }^{1 *}$, Yogi Mediantara ${ }^{2}$ \\ Universitas Surakarta \\ ${ }^{*}$ Koresponden: j_arramdhani@yahoo.co.id
}

\begin{abstract}
Abstrak
Tujuan penelitian adalah mengetahui bagaimana perubahan komunikasi sosial berubah secara massal dalam waktu singkat dengan adanya wabah covid-19 yang menular melalui manusia ke manusia, dengan angka korban yang terus meningkat dari hari kehari menurut laporan pemerintah (BNPB). Penelitian ini menggunakan metode kualitatif deskriptif dengan melakukan observasi dan wawancara yang tidak terstruktur dan informal, menyimpulkan sebagai hasil dan pembahasan, bahwa dari hasil pengamatan ini ,perubahan komunikasi dan kehidupan sosial antar manusia berubah dalam waktu cepat dengan munculnya prasangka terjadap orang yang dianggap ODP (Orang Dalam Pengawasan) bahkan penolakan jenazah akibat covid-19.
\end{abstract}

Kata kunci: Covid-19, Komunikasi, Sosial

\section{Abstract}

The aim of the research is how to change social communication that changes en masse with the covid19 outbreak that spreads through humans to humans, with the number of victims increasing steadily from day to day according to a government report (BNPB). This research uses descriptive qualitative method by conducting unstructured and informal observations and interviews, concluding the results and discussion, the results of research, communication and social life between people change in afast time with prejudice writing in Supervision) even rejecting the body because of covid-19.

Keywords: Covid-19, Communication, Social

\section{PENDAHULUAN}

Covid-19 (Corona Viruse Desease) merupakan penyakit yang saat ini sedang melanda dunia, beberapa negara terkena dampak virus tersebut, antara lain China, Italy, Amerika Serikat, Singapura dan belasan negara lainnya. V irus pertama kali ditemukan di kota Wuhan, Cina, pada akhir Desember 2019. Virus ini menular dengan cepat dan telah menyebar ke wilayah lain di Cina dan ke beberapa negara, termasuk Indonesia. Coronavirus adalah kumpulan virus yang bisa menginfeksi sistem pernapasan. Pada banyak kasus, virus ini hanya menyebabkan infeksi pernapasan ringan, seperti flu. Namun, virus ini juga bisa menye babkan infeksi pernapasan berat, seperti infeksi paru-paru (pneumonia), Middle-East Respiratory Syndrome (MERS), dan Severe Acute Respiratory Syndrome (SARS).

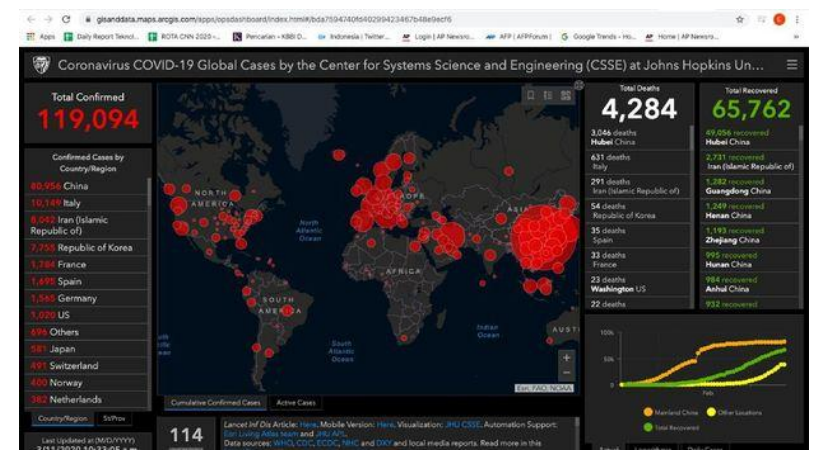

Gambar 1

Penyebaran Covid-19 (Global)

CNN Indonesia, 11 Maret 2020 
Virus Corona atau severe acute respiratory syndrome coronavirus 2 (SARS-CoV2) adalah virus yang menyerang sistem pernapasan. Penyakit karena infeksi virus ini disebut COVID-19. Virus Corona bisa menyebabkan gangguan pada sistem pernapasan, pneumonia akut, sampai kematian. Severe acute respiratory syndrome coronavirus 2 (SARS-CoV-2) yang lebih dikenal dengan nama virus Corona adalah jenis baru dari coronavirus yang menular ke manusia.

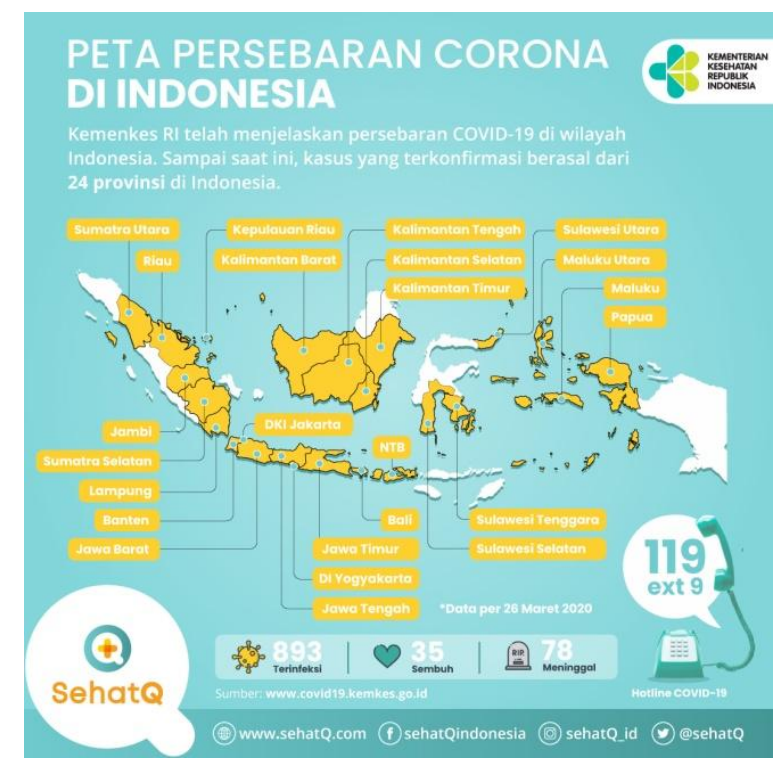

Gambar 2

Penyebaran Covid-19 (Indonesia)

Sehatq.com 02 Maret 2020

Virus ini bisa menyerang siapa saja, baik bayi, anak-anak, orang dewasa, lansia, ibu hamil, maupun ibu menyusui.Infeksi virus Corona atau COVID-19 disebabkan oleh coronavirus, yaitu kelompok virus yang menginfeksi sistem pernapasan. Pada sebagian besar kasus, coronavirus hanya menyebabkan infeksi pernapasan ringan sampai sedang, seperti flu. Akan tetapi, virus ini juga bisa menyebabkan infeksi pernapasan berat, seperti pneumonia, Middle-East Respiratory Syndrome (MERS), dan Severe Acute Respiratory Syndrome (SARS).

Ada dugaan bahwa virus Corona awalnya ditularkan dari hewan ke manusia. Namun, kemudian diketahui bahwa virus Corona juga menular dari manusia ke manusia. 


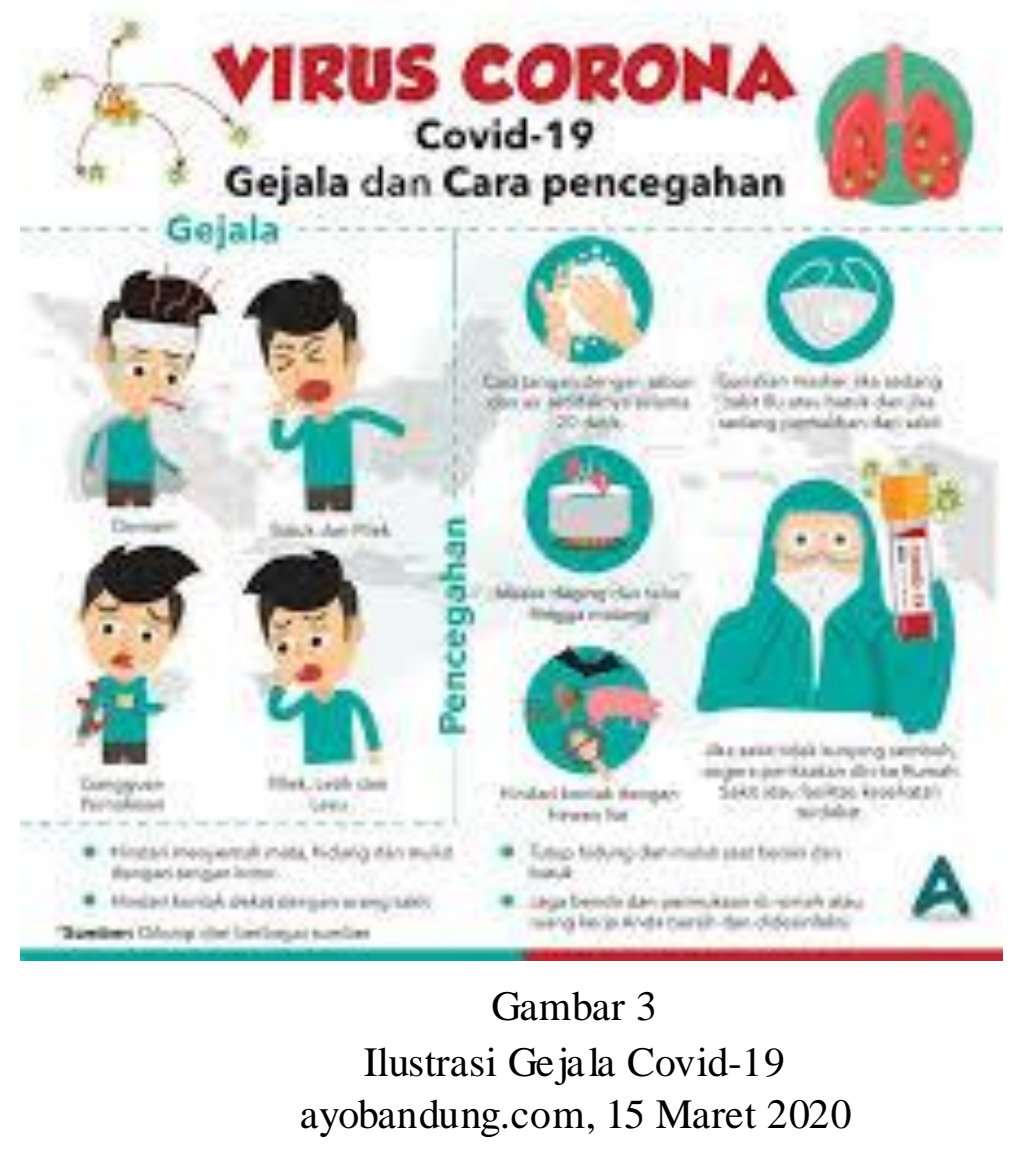

Seseorang dapat tertular COVID-19 melalui berbagai cara, yaitu:

- Tidak sengaja menghirup percikan ludah dari bersin atau batuk penderita COVID-19

- Memegang mulut atau hidung tanpa mencuci tangan terlebih dulu setelah menyentuh benda yang terkena cipratan air liur penderita COVID-19

- Kontak jarak dekat dengan penderita COVID-19, misalnya bersentuhan atau berjabat tangan

Virus Corona dapat menginfeksi siapa saja, tetapi efeknya akan lebih berbahaya atau bahkan fatal bila terjadi pada orang lanjut usia, ibu hamil, orang yang sedang sakit, atau orang yang daya tahan tubuhnya lemah, meningkatkan imun tubuh dengan asupan gizi yang cukup, sehingga mampu menangkal virus yang mudah menyebar Oleh karena itu, penularan penyakit antar manusia yang sangat rentan menjadi momok baru yang menakutkan banyak pihak.

Semakin mudahnya virus menular dan menyebar ke setiap daerah, membuat korban yang menderita corona semakin bertambah, sehingga antar manusia satu dan yang lain mengalami perubahan komunikasi sosial,. Istilah terbaru dalam fenomena covid-19 menjadi hal yang di kedepankan oleh setiap oaring yang mencegah penularan, sampai 
ketakutan yang berlebihhan terhadap orang lain yang dikenal ma upun yang tidak dikenal. Social distancing hanyalah salah satu dari sekian banyak istilah terkait virus Corona yang bermunculan dalam pandemi COVID-19.

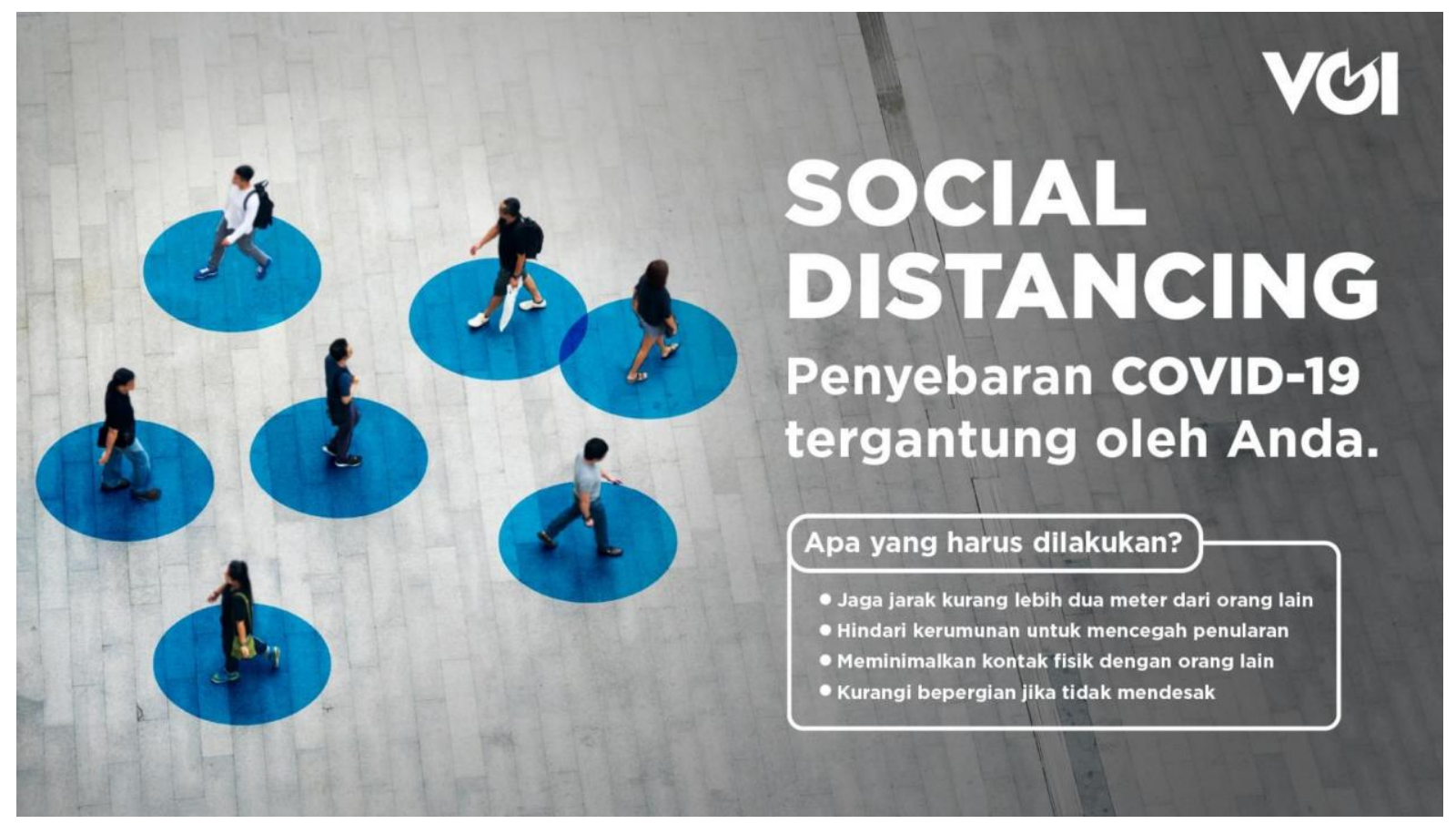

Gambar 4

Perubahan Sosial

Voi.id, 24 Maret 2020

Salah satu hal yang dibahas dalam mencegah penularannya virusnya adalah dengan sering mencuci tangan, mengajarkan layaknya anak-anak yang baru diajarkan cuci tangan sesering mungkin. Berwudu atau bersuci menurut agama is lam menjadi sorotan para pakar dalam melakukan pembersihan yang baik. Dalam penelitiannya, wudu dianggap bukan praktik higienis. Tapi, ada catatan kuat di bawahnya. Dari pandangan pakar barat, bersuci dengan air itu dianggap sebagai praktik kebersihan yang baik. Semua keutamaan wudu diulas di The Conservation. Itu merupakan sumber berita, analis is, dan komentar independen dari para pakar akademik. Bahkan The Washington Post dan kantor berita AP juga ikut melansirnya. Ada pesan kebersihan yang baik yang tersimpan dalam wudu. Dan semuanya, dinilai sangat ampuh untuk menghambat penyebaran virus corona covid-19.

Komunikasi adalah aktivitas yang dilakukan seseorang (komunikator) terhadap orang lain (komunikan) dengan tujuan tersampaikan sebuah pesan (message) dengan menggunakan a lat bantu atau langsung (channel). Hal ini bersumber dari pola komunikasi yang biasa dilakukan oleh masing-masing manusia dalam berkomunikasi personal ataupun kelompok sosial. Pola komunikasi yang sering dilakukan oleh manusia adalah antarpersonal, sehingga menjadi komunikasi interaktif, satu sama lain memerlukan 
feedback untuk melanjutkan tujuan dari komunikasi itu sendiri.

Perubahan yang terjadi da lam komunikasi sosial terlihat dan terasa saat wabah covid19 me lnada dunia, dengan penularan melalui manusia, membuat pola komunikasi menjadi tidak pada fungsinya, dengan terlalu banyak menggunakan alat bantu sebagai perantara, sehingga percakapan, gesture, logika percakapan seringkali mengalami mispersepsi dan asumsi baru terhadap komunikasi symbol.

Dampak lain dari covid-19 selain perekonomian yang dibahas pada media, yang sangat terasa adalah dampak sosial, dimana manusia satu lainnya menjadi anti dan takut akan mati akibat covid-19. Prasangka yang muncul bila orang bersin atau batuk, takut berdekatan karena takut tertular, bahkan penolakan jenazah covid-19 pada pemakaman umum di beberapa daerah, membuat rasa kemanusiaan menjadi berkurang akan kepedulian yang masih hidup dan yang sudah meninggal sekalipun.

CWN Home Nasional Internasional Ekonomi Olahraga Teknologi Hiburan Gaya Hidup - CNN TV

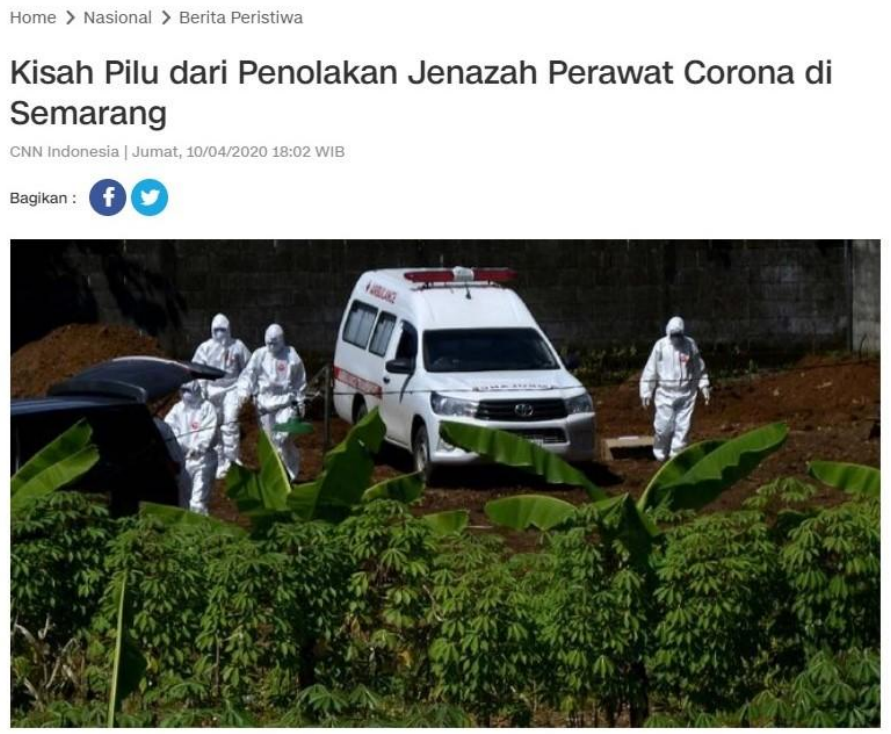

Gambar 5

CNN Indonesia, 10 April 2020, Penolakan Jenazah (Perubahan Sosial)

\section{METODE}

Metode penelitian yang digunakan dalam penulisan ini menggunakan metode penelitian kualitatif, yaitu bermaksud memahami fenomena yang sedang terjadi, yang sedang dialami subjek penelitian, baik secara sikap, perilaku, motivasi, tindakan. Penulis mendeskripsikan fenomena Covid-19 dengan menganalisa setiap informasi melalui media cetak, elektronik maupun online, dihubungkan dengan landasan teori komunikasi massa.

Pengumpulan data yang dilakukan dengan melakukan observasi dan wawancara tidak terstruktur dan informal dengan melibatkan orang lain secara random pada kasus Covid-19 
DOI: $10.30596 /$ persepsi.v\% vi\% i.4510

ini, melayangkan pertanyaan yang sama berkaitan dengan pengalaman dan nilai pada kasus covid-19 ini, untuk mendapatkan informasi sesuai tujuan tertentu.

\section{HASIL DAN PEMBAHASAN \\ Perubahan Sosial}

Manusia adalah mahluk ciptaan ALLAH SWT, Tuhan Yang Maha Esa dengan struktur dan fungsi yang sangat sempurna dibandingkan dengan mahluk ciptaan Tuhan lainnya.Manusia merupakan mahluk multidimensional, yang memiliki akal pemikiraan dan kemampuan berinteraksi secara personal maupun sosial. Manusia sebagai mahluk sosial karena tidak dapat hidup sendiri.

Pada saat ini, manusia sebagai mahluk sosial mengalami perubahan akibat serangan wabah penyakit covid-19, yang memaksakan kondisi dan situasi menjadi berubah, sehingga manusia menjadi hidup dengan hidupnya sendiri dan menjaga jarak dengan manusia lainnya. Ketakutan ada jenazah covid-19, dan takut sama setiap orang dengan kejadian pemberian uaang dengan cara dilempar hanya karena takut tertular, yang belum tentu mereka sebagai penular.

Kelompok sosial adalah kehidupan bersama manusia dalam himpunan atau kesatuankesatuan manusia yang umumnya secara fisik relatif kecil yang hidup secara guyub. Ada juga beberapa kelompok sosial yang dibentuk secara formal dan memiliki aturan-aturan yang jelas. Berdasarkan struktur kelompok dan proses sosialnya, maka kelompok sosial dapat dibagi menjadi beberapa karakter yang penting. Ada empat kelompok sosial yang dapat dibagi berdasarkan struktur masing-masing; Kelompok Formal-Sekunder, Kelompok FormalPrimer, Kelompok Informal- Sekunder, Kelompok Informal-Primier.

Konsep dasar perubahan sosial menyangkut tiga hal, yaitu:

1. Studi mengenai perbedaan

2. Studi dilakukan pada waktu yang berbeda (perbandingan)

3. Pengamatan pada sistem social yang sama

Artinya, bahwa untuk melakukan studi perubahan sosial, kita harus melihat adanya perbe daan atau perubahan yang menjadi fokus studi, lalu studi perubahan harus dilihat dalam konteks waktu yang berbeda, objek yang menjadi fokus harus lah objek yang sama sebagai komparasi. Para sosiolog telah menganalisis berbagai studi mengenai studi perubahan sosial. Dari berbagai studi tersebut dapat digolongkan penelaahan perubahan sosial tersebut berputar kepada enam persoalan pokok, yaitu:

1. Apakah yang sebenarnya mengalami perubahan?

Hal yang terjadi pada perubahan disini adalah komunikasi interaksi sosial antar manusia dengan dampak covid-19 yang mewabah di Indonesia khusus nya. Hal ini memicu kehidupan di masyarakat mengalami perubahan komunikasi seperti biasanya.

Menurut Soeryono Soekanto (2002: 65), kontak sosial berasal dari bahasa latin con atau cum (bersama-sama) dan tango (menyentuh), jadi, artinya secara harfiah adalah bersama-sama menyentu. Secara fisik, kontak sosial baru terjadi apabila adanya hubungan fisikal, sebagai gejala sosial hal itu bukan semata-mata hubungan badaniah, karena hubungan sosial terjadi tidak saja secara menyentuh seseorang, namun orang 
dapat berhubungan dengan orang lain tanpa harus menyentuhnya. Misalnya kontak sosial sudah terjadi ketika seseorang berbicara dengan orang lain, bahkan kontak sosial juga dapat dilakukan dengan meng gunakan teknologi.

2. Bagaimana hal tersebut mengalami perubahan?

Perubahan interaksi sosial yang terjadi saat ini terjadi karena salah satu dampak yang terjadi dengan adanya fenomena wabah covid-19, selain dampak pada ekonomi, dampak lingkungan. Covid-19 mulai di kota Wuhan, China, mulai menularkan ke manusia dan menyebarkan ke beberapa Negara, mulai berjatuhan korban tertular sampai meninggal dengan angka yang tinggi. Kebijakan pada pemerintah di Negara masing-masing mulai diterapkan, seperti social distancing, karantina, PSBB, sampai lockdown pada daerah tertentu. Hal ini memunculkan pembatasan komunikasi manusia secara interaksi kontak sosial (tatap muka, menyentuh secara fisik) menjadi berkurang, dan terarah pada aktivitas komunikasi dunia maya.

Secara konseptual kontak sosial dapat dibedakan antara kontak sosial primer dan kontak sosial sekunder. Kontak sosial primer, yaitu kontak sosial yang terjadi secara langsung anatara seseorang dengan orang atau kelompok masyarakat lainnya secara tatap muka. Sedangkan kontak sosial sekunder terjadi melalui perantara yang sifatnya manusiawi maupun dengan teknologi.

3. Apa tujuan perubahan itu?

Dampak sosial yang terjadi pada masyarakat saat ini meski tidak diharapkan, namun memmiliki tujuan yang disepakati oleh sebagian, dengan kebijakan yang dimunculkan dan dukungan dari masyarakat yang mendukung hal tersebut, membantu dalam menekan penyebaran wabah covid-19 yang sedang terjadi. Dengan berbagai usaha dihadirkan dengan istilah-istilah baru, seperti:

\section{a. Social distancing}

Menurut Centers for Disease Control and Prevention (CDC), arti istilah 'social distancing' atau 'pembatasan sosial' adalah menghindari tempat umum, menjauhi keramaian, dan menjaga jarak optimal 2 meter dari orang lain. Dengan adanya jarak, penyebaran penyakit ini diharapkan dapat berkurang.

\section{b. Isolasi dan Karantina}

Perbedaannya, isolasi memisahkan orang yang sudah sakit dengan orang yang tidak sakit untuk mencegah penyebaran virus Corona, sedangkan karantina memisahkan dan membatasi kegiatan orang yang sudah terpapar virus Corona namun belum menunjukkan gejala.Berbagai pakar menganjurkan untuk melakukan karantina di rumah atau isolasi mandiri selama setidaknya 14 hari. Selama karantina, Anda dianjurkan untuk tinggal di rumah sambil menjalani pola hidup bersih dan sehat, tidak bertemu orang lain, dan menjaga jarak setidaknya 2 meter dari orang-orang yang tinggal serumah.

\section{c. Lockdown}

Istilah 'lockdown' berarti karantina wilayah, yaitu pembatasan pergerakan penduduk dalam suatu wilayah, termasuk menutup akses masuk dan keluar wilayah. Penutupan jalur keluar masuk serta pembatasan pergerakan penduduk ini dilakukan untuk mengurangi kontaminasi dan penyebaran penyakit COVID-19. 


\section{d. PSBB (Pembatasan Sosial Berskala Besar)}

Kementrian Kesehatan melakukan pembatasan ini pada daerah terttentu, dengan tujuan yang lebih besar karena melihat kondisi lingkungan masing-masing. Misalnya korban cukup banyak, atau yang belum terkena tidak melaksanakan beberapa aturan yang berlaku (melanggar) sehingga mengganggu jalannya aktivitas penyembuhan.

\section{e. Pasien dalam pengawas an (PDP) dan orang dalam pemantauan (ODP)}

PDP dan ODP merupakan definisi yang digunakan untuk mengelompokkan individu berdasarkan:

- Gejala demam dan/atau gangguan pernapasan

- Riwayat perjalanan ke daerah pandemi infeksi virus Corona atau tinggal di daerah tersebut selama 14 hari terakhir sebelum gejala timbul

- Riwayat kontak dengan orang yang terinfeksi atau diduga terinfeksi COVID-19 dalam 14 hari terakhir sebelum geja la timbul

Secara umum, ODP dan PDP bisa dibedakan dari gejala yang dialami. Pada ODP, gejala yang muncul hanya salah satu antara demam atau gangguan pernapasan, seperti batuk, pilek, sakit tenggorokan, dan sesak napas. Sedangkan pada PDP, sudah ada gejala demam maupun gangguan pernapasan.

Terhadap PDP, dilakukan rawat inap terisolasi di rumah sakit, pemeriksaan laboratorium, dan pemantauan pada orang lain yang memiliki kontak erat dengan PDP tersebut.

Sementara ODP harus menjalani isolasi di rumah dan kondisinya akan dipantau setiap hari selama 2 minggu, menggunakan formulir khusus.

Jika kondisi ODP mengalami perburukan dan sudah memenuhi kriteria PDP atau hasil laboratoriumnya positif terinfeksi virus Corona, maka ODP tersebut harus dibawa ke rumah sakit.

\section{Seberapa cepat perubahan itu?}

Perubahan ini terjadi sangat cepat sampai masyarakat mengalami banyak kejutan, dengan pembatasan fisik, pembatasan belanja, pembatasan beekerja dikantor masing-masing, dan harus WFH (Work From Home) melakukan segala pekerjaan dan tugas harian dari rumah, dengan mengandalkan teknologi. Interaksi yang dilakukan selama ini menggunakan interaksi komunikasi kontak sosial, dengan cepat menjadi masyarakat global dan pembentukan cybercommunity, yaitu Community masyarakat adalah kelompok orang yang menempati sebuah wilayah (territorial) tertentu, yang hidup secara relatif lama, saling berkomunikasi, memiliki simbol-simbol dan aturan tertentu serta sistem hukum yang mengontrol tindakan anggota masyarakat, memiliki sistem stratif ikasi, sadar sebagai bagian dari anggota masyarakat tersebut serta relatif dapat menghidupi dirinya sendiri.

Perkembangan teknologi informasi juga tidak saja mampu menciptakan masyarakat dunia global, namun secara materi mampu mengembangkan ruang gerak kehidupan baru bagi masyarakat sehingga tanpa disadari, komunitas manusia telah hidup dalam dua dunia kehidupan, yaitu kehidupan masyarakat nyata dan kehidupan masyarakat maya 
(cybercommunity). Masyarakat nyata adalah sebuah kehidupan masyarakat yang secara inderawi dapat dirasakan sebagai sebuah kehidupan nyata, dimana hubungan-hubungan sosial sesame anggota masyarakat dibangun melalui penginderaan. Secara nyata kehidupan masyarakat manusia dapat disaksikan sebagaimana apa adanya. Sedangkan kehidupan masyarakat maya adalah sebuah kehidupan masyarakat manusia yang tidak dapat secara langsung diindera melalui penginderaan manusia, namun dapat dirasakan dan disaksikan sebagai sebuah realitas.

Kemajuan teknologi manusia, khususnya teknologi informasi secara sadar membuka ruang kehidupan manusia semakin luas, semakin tanpa batas dengan indikasi manusia semakin luas, semakin tanpa batas dengan indikasi manusia sebagai penguasa (khalifah) di planet bumi dan galaks inya.

5. Mengapa terjadi perubahan?

Perubahan terjadi karena manusia takut mengalami kematian akibat wabah covid-19, sehingga setiap cara dilakukan untuk menekan penyebaran penyakit tersebut.

6. Faktor-faktor apa saja yang berperan di dalam perubahan tersebut?

Beberapa hal yang mendukung adanya perubahan adalah perkembangan yang disampaikan melalui media massa kepada masyarakat tentang penyebaran, perkembangan, pencegahan, penekanan wabah covid-19 agar cepat lenyap dari Indonesia dan muka bumi lainnya, sehingga kembali normal kehidupan manusia melakukan komunikasi kontak sosial.

\section{KESIMPULAN}

Faktor yang berperan dalam perubahan akibat Covid 19 adalah pemerintah dalam pemangku kebijakan tertinggi bersama lembaga swasta yang lain, seperti rumah sakit dan tenaga-tenaga sukarela yang memiliki kepedulian bersama untuk menekan angka penularan ini, dan disampaikan melalui media massa, dimana masyarakat dihimbau untuk melakukan apa yang diperintahkan secara tegas demi kepentingan bersama, namun tidak mencerna pembatasan sosial tersebut bukan menjadi lemahnya kepedulian terhadap orang lain.

\section{DAFTAR PUSTAKA}

Martono, Nanang. 2011. Sos iologi Perubahan Sosial. Perspektif Klasik, Modern, Postmodern, dan Psikolonial. Edisi 1. PT Raja Grafindo Persada. Jakarta.

Bungin, Burhan. 2014. Sosiologi Komunikasi. Teori, Paradigma, dan Diskursus Teknologi Komunikasi di Masyarakat. Edisi 1. Kencana Prenada Media Group. Jakarta.

Suprapto, Tommy, 2009. Pengantar Teori dan Manajemen Komunikasi. Edisi 1. MedPress. Yogyakarta.

Mulyana, Deddy, 2003. Metodologi Penelitian Kualitatif. Paradigma Baru Ilmu Komunikasi dan Ilmu Sosial Lainnya. . PT Remaja Rosdakarya.Bandung.

Herdians yah, Haris. 2010. Metodologi Penelitian Kualitatif Untuk Ilmu-ilmu Sosial. Salemba Humanika. Jakarta. 